\title{
ILLUSION-MAKING AND ILLUSION-BREAKING: ALL MY SONS ON THE ALBANIAN STAGE BEFORE THE COLLAPSE OF COMMUNISM
}

\begin{abstract}
This paper aims to analyze how Arthur Miller's All My Sons was received on the Albanian stage by the end of the 1980s, with a significant delay of forty years since its first staging on Broadway. The purpose of staging this play in the Albanian context was to unmask potential materialism and social conflicts inside the American family/society. Despite the delay in staging All My Sons, this play represents one of the few approved American "traces" on the Albanian theater during communism. For my analysis, I will rely on cultural translation and reception theories. Through the "adapters" of Patrice Pavis, the "domestication" of Lawrence Venuti, as well as Gerard Genette's "paratext", I will examine the translation and the reception of the play in the target culture under opposing political circumstances.
\end{abstract}

Key words: communism, capitalism, propaganda, domestication, culture

\section{Introduction}

Arthur Miller's All My Sons has been running successfully on different stages all over the world for more than seventy years. It became part of the Albanian stage only in 1988, with an unusual delay, more than forty years since its first staging on Broadway, Coronet Theater, New York City in January 1947. It had a relatively noticeable impact, but most importantly, the play was adapted to comply with the political and social situation of Albania during that time. Arthur Miller escaped heavy isolationism and became part of the Albanian stage several times with moderate criticism. His plays were purposely added to the repertoire to enact criticism towards the American way of life in the eyes of the Albanian audience. In an attempt to follow the same communist principles of all the other ex-communist countries such as the Soviet Union, Yugoslavia, and Bulgaria; Albania, last but not least, decided to bring pieces of American culture, served as a counter-response to capitalism, the primary enemy of communism. Based on the observations of scholar Kornelia Slavova:

\footnotetext{
"Faculty of Classical and Modern Philology, Sofia University "St. Kliment Ohridski”, 1504 Sofia, 15 Tsar Osvoboditel Blvd; e-mail: nikolla.elgoni@gmail.com
} 
After WWII, Miller took by surprise the theatre stage in Great Britain, Germany, France, Italy, Greece, Spain, the U.S.S.R., and his huge success in Europe over the years has prompted some critics to call him "the most European American playwright" (Perez 214). Miller did not simply add to the popularity of American drama across the Atlantic but he also rehabilitated the socially engaged theatre by presenting a different America, marked by social conflicts, political tensions, and atomic anxieties - unlike the clichéd Broadway and Hollywood images of the land of prosperity and opportunity. (Slavova 2018: 70)

\section{All My Sons beyond the Iron Curtain (1940-1990)}

From a chronological point of view, Arthur Miller's All My Sons, touched the East European stage, more specifically, the Balkan stage, very soon after its success in the USA. It started with the performance in Sofia, Bulgaria, at Sofia Theater "Trudov Front" in 1948 (Slavova 2014: 96), only one year after its first staging on Broadway. It reached the National Theater in Bucharest, Romania, in 1948 for the first time. The translation of the same play in Russian appeared in 1948, and it entered the repertoire at Moscow Theater of Drama in 1958. The reception of Western influence in Yugoslavia began with Death of a Salesman, A View from the Bridge and The Crucible (the 1950s - 1960s) performed first at Belgrade Drama Theater. In Greece, All My Sons was performed for the first time at the National Theater of Northern Greece, in 1979-1980. Moreover, last but not least, All My Sons reached the National Theater in Tirana, Albania in 1988, right before the collapse of communism. The most crucial play of Miller for the Albanian stage was Death of a Salesman performed at the National Theater in 1986. Moreover, other plays written by Arthur Miller escaped the harsh isolationism of communist propaganda in Albania and reached the stage with a significant delay compared to the other ex-communist countries in Eastern Europe, including Bulgaria and its neighbor, ex-Yugoslavia.

\section{Literary theory}

One of the means used for the analysis of the adaptation of All My Sons in Albanian is The Hourglass of Culture by Patrice Pavis, more specifically, the adaptors mentioned in Pavis's book.

These adapters are not someone charged explicitly with transposing the contents and forms from one cultural shore to another. They are a group of enunciators intervening at all levels and every stage of the production. 
They are subject to the institutional imperatives of the target culture, which tends to preserve from the foreign culture whatever suits its expectations, reinforces its convictions, and renews it in adapting to the restraints of actual production. (Pavis 1996: 104)

In my analysis of the Albanian version of All My Sons, I will go beyond the linguistic aspects of translation towards social and cultural practices, considering history, ideology, cultural and social differences. Lawrence Venuti's theory is equally important to my study. According to Venuti, two of the essential types of translation strategies are "foreignization" and "domestication".

Domestication involves the ethnocentric reduction of the foreign text to target-language cultural values. Foreignization, on the other hand, entails choosing a foreign text and developing a translation method along lines which are excluded by dominant cultural values in the target language. (Venuti 1995: 1)

For the analysis of the play's reception, I will make use of Gerard Gennette's Paratext: Thresholds of Interpretation. By studying the translation of Miller's All My Sons, many questions can arise: How is culture transferred from the American reality of the $20^{\text {th }}$ century to the small, isolated, ex-communist Eastern European country? In what ways has the Albanian version implied cultural differences?

\section{A social play in tormented times}

"All My Sons is a play based upon a true story which Arthur Miller's then motherin-law pointed out in an Ohio newspaper. The news story described how in 1941-43 the Wright Aeronautical Corporation based in Ohio had conspired with army inspection officers to approve defective aircraft engines destined for military use" (Meyers 2009: 92). All My Sons was written and staged in 1947. The action takes place immediately after the Second World War, in a family that became rich by taking advantage of the opportunities they had. Drama was running deeply in the Kellers' home. After a few years, the decisions taken during the war had drastic consequences for all the members of the family personifying the American family with its deep problems. Arthur Miller chose to develop such a play that intensified the urge to understand the complexity of the American way of life.

While a transitional political period was knocking at Albania's door, the theater did not cease to attempt staging Arthur Miller's All My Sons, criticizing irresponsibility and greed of American society in the eyes of the Albanian audience. In my analysis, 
I will emphasize the translation and the reception of All My Sons following the value system, ideological perceptions, and norms of the Albanian culture of that time. All My Sons was translated for the first time into Albanian for the production of 1988 in Andon Zako Çajupi Theater in Korça, directed by Dhimitër Orgocka. Taking into consideration the cultural difference between source culture and target culture, I will focus on the translation of some specific cultural terms and "the intended" reception induced by theater program notes and post-performance guiding lines. The translation of All My Sons shows substantial ideological implications, reframing the source culture into the language of class clash and investigative process, a practice very often used during communism to blame people for political propaganda.

\section{Cultural translation, All My Sons in the Albanian context}

\subsection{Religious terms, astrology and curses}

In order to facilitate the analysis, I have elaborated groups and subgroups to show the level of interference in the original play by the translator guided by political principles imposed by communist propaganda. There were significant cuts, modifications, and compresses manifested throughout all the translation in the target language. One major group covers cuts in religious terms, astrology, and curses. Some of the religious words used in the source language are "for God's sake" (Miller 1947: 32), "Gosh" (Miller 1947: 19), "Jesus God" (Miller 1947: 60), "God in Heaven" (Miller 1947: 60), "Honest to God" (Miller 1947: 49). The examples mentioned below indicate the omission of long phrases and entire parts of dialogues without an attempt to adapt or transform them into the target language. For instance, "That's why there is God. Otherwise, anything could happen. But there's God so certain things can never happen" (Miller 1947: 22); "You don't want to be the voice of God, do you?" (Miller 1947: 45); "Chris, a man can't be a Jesus in this world!" (Miller 1947: 69).

Another significant subgroup is astrology. For example, words and phrases like "horoscope" (Miller 1947: 4), "according to the stars" (Miller 1947: 4), "that's why he took up astrology" (Miller 1947: 51), "every man does have a star" (Miller 1947: 62), "to watch his star go out" (Miller 1947: 62). Another subgroup includes curses like, "Goddam newspaper" (Miller 1947: 11), "Goddam business" (Miller 1947: 60), "to hell with the restaurant!" (Miller 1947: 49). No translation of these phrases is evident in the target language, lacking an explanation for such an action. Nevertheless, a logical justification stands in the atheist nature of the country during those times. Let us not forget that Albania outlawed public religious practices between 1967 and 1990, denying all forms of religious expressions. 


\subsection{American pop culture}

Terms related to the source culture, and more precisely, American pop culture, were omitted or transformed moderately into the target culture. For instance, phrases like "ten dollars" (Miller 1947: 6), "five dollars" (Miller 1947: 36) were substituted with only the word "dollar" (Teatri IV 1987: 50) or "shumë dollarë" (Teatri IV 1987: 74) (meaning: "many dollars" in Albanian), in the target culture. Other phrases like "post toasties" (Miller 1947: 24), "playland" (Miller 1947: 39), "Andy Gump" (Miller 1947: 52), were not translated and transferred to the target culture due to the unfamiliarity with the American way of life in Albania. This way, the audience had lost some essential elements from the source culture. The omission of such terms despite slight theatrical liberalization came through a lack of knowledge, information, and contact with the American society for a prolonged period. Although the decline of the regime was near, party guidelines were still respected. After 50 years of prosecution for "little mistakes" in small details, the artists, directors, and translators were afraid to take a step of innovation.

\subsection{Emotional expressions}

Another major group within cultural elements is related to the transformation of sensual terms and emotional expressions in the play. Some of the expressions omitted were "I can smell the perfume over the phone" (Miller 1947: 5), "he's a doctor, women are supposed to call him up" (Miller 1947: 6), "Give me a kiss, Ann. Give me a [...] God, I kissed you, Annie, I kissed Annie. How long, how long I've been waiting to kiss you!" (Miller 1947: 28), "Casanova" (Miller 1947: 27). Terms like "sweetheart" (Miller 1947: 35), "The air is sweet" (Miller 1947: 27), "darling" (Miller 1947: 37) were mostly not translated. Expressions of love and kindness through body language took place only in private places. According to communist principles in Albania, all sexual or emotional expressions in public were a violation of the Albanian social norms, seen as pure elements of western influence, identified as "modern influences". Whereas, the communist party preached clear communist principles that everyone was obliged to follow.

\subsection{Geographical terms and famous names}

Another major group of cuts in the play contains geographical terms. Some of the states or cities were mentioned in the translation but to a reduced extent. "New Orleans" and "Cleveland" were not mentioned at all. "New York" was mentioned more often most probably for its popularity worldwide. Another group contains cuts in names of companies and world celebrities. Some of the well-known names for the 
western world became invisible to the Albanian audience. For instance, names of companies: "General Motors" (Miller 1947: 53), well-known names such as "George Bernard Shaw" (Miller 1947: 30), "Mahatma Gandhi" (Miller 1947: 49), did not appear as translated. The reason for the avoidance of such names is the unfamiliarity of the audience with such figures. It is essential to mention that Albanians under communism were taught only on their national figures and solely in connection to the communist front. National heroes and contributors who were ideologically opposing communism were censured and never allowed to be consulted or read until the collapse of communism. Another subgroup is the change of the character's names. One of them is "Steve" (Miller 1947: 26), mentioned all over the play. The translator had changed "Steve" into "Hardi", perhaps to avoid trendy American names such as "Steve", perceived as a foreign element by the Albanian audience.

\subsection{Food and drinks}

The last group contains terms related to food and drinks, which were unknown to the target culture. The play's adaptation in the target language suffered an impoverishment in such words limiting the transmission of the author's true intention. For example, "I got a ham in the icebox, and frozen strawberries, and avocados, and ..." (Miller 1947: 49), "cracked as coconuts" (Miller 1947: 61), "tuxedos" (Miller 1947: 32), "grape drink" (Miller 1947: 33), "doughnut" (Miller 1947: 7), "hot dogs" (Miller 1947: 30). Such terms were not familiar to the Albanian context before the 1990s. As a consequence, there was a lack of knowledge of such terms before the collapse of communism. For this reason, the translator had reduced the vocabulary turning the original play into a simplified version.

\section{Translation and performance}

Furthermore, there is a visible alteration in the translation of the play in comparison to the performance. "Performances may be seen as cultural practices that conservatively reinscribe or passionately reinvent the ideas, symbols, and gestures that shape social life. Such reinscriptions or reinventions are, inevitably, negotiations with regimes of power" (Diamond 1996: 67). The translator has adapted some of the elements of the source culture domesticating them, while the staging omitted them completely. For example, in the performance of the First Act, everything starts directly with the episode of the tree, prioritizing the primary concern of Kate, the return of Larry, the dilemma of him being alive or dead.

A sense of anxiety permeates the audience immediately since the very first beginning of the performance. "E ke parë se çka ndodhur me pemën e Lerit" (Teatri 
IV 1987: 56) states Joe and Chris replies by saying, "E kam parë" (Teatri IV 1987: 56). In English: "Did you see what happened with Larry's tree?" states Joe and Chris replies: "I saw". Differently from the performance, the translation of the play before the staging starts with Joe asking Chris, "Eni u ngrit?" (Teatri IV 1987: 55) and, moreover, Joe answering "Nëna po i jep mëngjesin në kuzhinë" (Teatri IV 1987: 55). The English version of these two first lines is: "Is Ann already up? Mother is serving her breakfast in the kitchen". The rest of the First Act has significant omitted parts in which details of the everyday life of an American family is lacking. There were comprehensive transformations of the source culture constantly creating a detachment losing the essence and showing very little in the performance. The focus of the target culture intended to domesticate or omit the "bourgeois society" of America, the forms of entertainment, and the relationships between couples.

Another element to be mentioned is divorce, perceived as an unacceptable process that married couples could undergo in the Albanian society. Consequently, the phrase "Your Mother [...] She's not getting a divorce, heh?" (Miller 1948: 21) was removed. Such discrepancy indicates an evident unfamiliarity with the American way of life, thus diverging the cultural experience of post-war America and communist Albania. It is essential to state here, by the end of the last Act, Chris's definition of himself in the performance as "Jam një amerikan praktik" (Teatri IV 1987: 108), (I am a pragmatic American), and repeating himself three times, to show the failure of the American pragmatism that brought a disastrous situation to the Kellers. There is a sense of prejudice, gab of knowledge and mostly, tendency to aggravate the imperfections of American life or to twist them in a pejorative way. One question that one can raise here is: Why precisely was the consumer culture under threat in the target culture? Political propaganda was the leading element in every aspect of Albanian society.

The observation of the overall domestication level in the target language influenced all aspects of translation. Some of these aspects include lack of familiarity with the American reality, failure to render historical allusions, a literal translation of symbolical names and omission of a significant number of relevant information that renders the play complete. For example: "he has a cup of coffee in one hand, part of a doughnut in the other" (Miller 1947: 7). The sense of this phrase is the expression of American culture, "grab and go" culture, the American pragmatism. In the target culture, rushing to work with a cup of coffee in your hands was an inexistent concept. Another example to be mentioned: "why'd they take our hammock away?" (Miller 1947: 19), was missing in the adaptation. In the Albanian culture, the use of unusual objects for relaxation or entertainment was unknown. Only the self-defined "politicalelite" could benefit from particular commodities and privileges in daily life. 


\section{Reception}

Another attempt to domesticate the play, despite the short temporal distance with the collapse of communism, was the pre-performance guiding lines and the postproduction articles published in the local magazines or newspapers to give an outlook or lenses for the understanding of the play. In terms of Gerard Genette's "paratext" which he represents "more than a boundary or a sealed-border, as a threshold" (Genette 1997: 5). In the Theater Program note and the pre-performance guiding lines published before the staging of the play, there was a short description of the play and the main characters to criticize the American pragmatism and the bourgeois society. Theater Program notes served as a means of information for the spectators regarding the playwright's bibliography, his works, as well as the cast of stage performance.

Theater Program notes, pre- and post-performance guiding lines were powerful instruments in the hands of the anonymous critics, state commissions reviewing plays before performance, directing the eyes of the audience wherever their attention was needed and approved. Different from the Bulgarian context where, as emphasized by scholar Slavova, "The incorporated comments by the actors throw additional light on the performance: each actor quotes a key line from his/her respective character, thus creating a rather authentic feel instead of coming up with moralizing comments" (Slavova 2018: 71), in the Albanian context, actors were limited to interpreting their role with no space to quote their own critical lines in the play before or after performance.

\section{Conclusions}

The analysis of Arthur Miller's All My Sons in Albanian sheds light on the interpretation and the representation of cultural differences in the source and target culture. It helps in tripping over the intercultural transfer of the American play on the Albanian translation and stage where the terms and phrases have been seized, transferred, adopted and transmitted following the different systems of political and social significance in both source and target culture. The confrontation of the two versions of the play in English and Albanian has proved that the translation practices and adaptations are always involved with other elements like politics, propaganda, knowledge, transforming the original using norms and traditions of the target culture. According to Lawrence Venuti, "domestication involves an ethnocentric reduction of the foreign text to target-language cultural values. This entails translating in a transparent, fluent, "invisible" style to minimize the foreignness of the target culture" (Venuti 1995: 469). In the context of All My Sons, the translation rewrites the original by adjusting and transforming the meaning. This version of translation demonstrates a violent cultural transference through domesticating and criticizing the American capitalist reality and values characterized as a potential threat from 1944 to 1990. 


\section{References}

Diamond, E. (1996). Performance and Cultural Politics. London: Routledge.

Gennette, G. (1997). Paratexts: Thresholds of Interpretation. Cambridge: Cambridge University Press.

Meyers, J. (2009). The Genius and the Goddess: Arthur Miller and Marilyn Monroe. Chicago: University of Illinois Press.

Miller, A. (1947). All My Sons. New York: Reynal and Hitchcock.

Pavis, P. (1992). Theatre at the Crossroads of Culture. London: Routledge.

Pavis, P. (1996). The Intercultural Performance Reader. London: Routledge.

Perez, M. D. (2001). Teatro Europeo Contemporaneo. La Laguna: Cultura y Deportes.

Slavova, K. (2014). American Drama on the Bulgarian Stage. Theater as a Translation of Cultures. Sofia: Polis Publishing House.

Slavova, K. (2018). Between Politics and Poetics: Arthur Miller's Transnational America on the Bulgarian Stage (1948-2011). In: A. Ciugureanu, E. Vlad and N. Stanca (eds.), National and Transnational Challenges to the American Imaginary, Bern: Peter Lang, 69-80.

Teatri IV Theater Archives. (1987). Ishin të Gjithë Bijtë e Mi. Teatri IV. Korçë: Theater Archives, 54-112.

Venuti, L. (1995). The Translator's Invisibility: A History of Translation. London: Routledge. 